seconded for service with the Ministry of Supply, where he acted as deputy director of scientific research.

Prof. Linstead's scientific work is characterized by remarkable thoroughness and breadth of view; he is clearly not interested in quick returns and likes to tackle problems of fundamental significance. His best-known contributions include studies of unsaturated acids, carbocyclic fused-ring compounds and the discovery of a very interesting new class of synthetic pigments, the phthalocyanines; his recent investigation on the stereochemistry of catalytic hydrogenation is a particularly finished piece of work. Prof. Linstead, who is forty-three, was elected a fellow of the Royal Society in 1940 and is an honorary M.A. of.Harvard University.

\section{Wellcome Museum of Medical Science :}

Appointments

Wing-Commander C. J. Haoketr has been appointed director of the Wellcome Museum of Medical Science in succession to Dr. S. H. Daukes, who has been responsible for the development of this Museum. during the last twenty-six years. Dr. Hackett, who was a research fellow in tropical medicine of the Medical Research Cauncil and who has done important work on yaws and other tropical diseases, will take up his new appointment as soon as he has been released from the Royal Air Force.

Dr. E. Ashworth Underwood has been appointed director of the Wellcome Historical Medical Museum and the Wellcome Historical Medical Library, and will take up his new duties as soon as he can be released from his present post of medical officer of health and chief sohool medicel officer of the County Borough of West Ham. Dr. Underwood has held his present post for the past eight years. Before that he was medical officer of health of the Metropolitan Borough of Shoreditch, deputy medical officer of health of the city of Leeds, and lecturer in public health in the University of Leeds. In this field he has written widely on tuberculosis, on epidemiology and allied subjects. Dr. Underwood is well known for his activities in the sphere of the history of medicine. During the past five years he has been honorary secretary of the History of Medicine Section of the Royal Society of Medicine. He has contributed to the Proceedings of that Society, and to other journals, studies on the history of certain infectious diseases, on the medical importance of Lavoisier and the French chemists, on the earlier anatomists and on other subjects. He has for some time been collaborating with Prof. Charles Singer in work on Vesalius.

\section{National Research Council (Canada)}

Three new members have been appointed to the National Research Council (Canada) and two other members have been reappointed. The new members are: Mr. Percy Bengough, president, Trades and Labour Congress of Canada, Ottawa; Dr. Paul Gagnon, director, Department of Chemical Engineering, Laval University, Quebec ; and Prof. David A. Keys, Macdonald professor of physics and chairman of the Physical Sciences Group of the Faculty of Arts and Science, MeGill University, Montreal. The two members reappointed are Prof. J. A. Gray, Chown science research professor, Queen's University, Kingston, Ontario, and Mr. Arthur Surveyer, consulting engineer, Montreal, Quebec.

\section{Scientific Co-operation with Czechoslovakia}

SIR AlFred Egerton, one of the secretaries of the Royal Society of London, has left for a visit to Prague to convey the greetings of the Royal Society on behalf of the men of science of Great Britain to their colleagues in Czechoslovakia. He will be the guest of the rector of the Charles University in Prague and will discuss with him and his colleagues what aid British science can give to the rehabilitation of science and scientific education in their country. It is hoped that this visit may do much to enable the people of Czechoslovakia to re-establish firm scientific contacts with men of science throughout the world. Sir Alfred Egerton is taking with him, for the Masaryk University at Brno and the Royal Bohemian Society of Sciences at Prague, scientific publications of the Royal Society issued during the war years.

\section{Czech Botanists During the War}

BOTANICAX researoh, like that in other branches of science, almost ceased in Central Europe when the Germans marched in. With their laboratories closed, Czech botanists retreated to their gardens and homes, where they had the leisure in which to examine the results of previous researches, conducted before such work was interrupted. Prof. Bohumil Nømec, already the author of several standard Czech botanical works, wrote a comprehensive treatise on "Plant Life", in which he used more than seven hundred original illustrations. In addition, he published a more popular work, "The Green Kingdom", and also articles dealing with the mechanism of plant growth, movement and reproduction for biological and scientific journals, which seem to have increased in importance as the nation's position became more desperate. Dr. S. Prát continued to publish sections of his "Rostlinopis", a kind of botanical encyclopædia inspired, apparently, by the work a hundred years ago of those two pioneers of botany in Bohemia, the brothers J. S. and K. B. Presl, who used the same title for their "Botany", which they did not live to complete.

In mycology, Dr. J. Peklo published several long papers (including a seventy-page monograph) on the geneties of certain fungi and the problem of 'relative sexuality' among lower plants. As these contributions to botany are written in Czech they will not receive much attention until detailed abstracts are available in English. Not all Czech botanists were fortunate enough to remain unmolested. Prof. Nømec's son was obliged to hide in the forests of Slovakia, and the exposure has impaired his health. Dr. Augustus Bayer, professor of botany in the Masaryk University of Brno, was executed by the Germans in 1942. He was a specialist on the development and enatomy of wood tissues. Dr. Bayer, who was sixty years of age, had also been engaged upon problems in forestry and agriculture, and indeed had gained an inter. national reputation as an expert in applied botany and dendrology.

\section{Jubilee of the Newcomen Society}

THE next meeting of the Newcomen Society, to be held on November 14, will mark the completion of twenty-five years activity of the Society. The officers of the Society in 1920 included A. Titley as president, three vice-presidents, ten members of council and H. W. Dickinson as honorary secretary and treasurer, of these fifteen members, seven have served on the Council during the whole twenty-five years, Dr. 